\title{
The Determination of Infection and Damage Rates of the Alfalfa Seed Chalcid, Bruchophagus roddi Gussakovskiy, 1933 (Hymenoptera, Eurytomidae) in Alfalfa Seed Stored in the Eastern Region of Turkey*
}

\author{
Celalettin GÖZÜAÇIK ${ }^{1}$, Abdullah İREÇ²
}

\begin{abstract}
This study was conducted to determine the infection and damage rates of the alfalfa seed chalcid, Bruchophagus roddi Gussakovskiy, 1933 (Hymenoptera, Eurytomidae) in alfalfa seeds stored at 22 locations in Iğdır, Kars and Van provinces of the Eastern Anatolia region in 2013-2014 years. In the study carried out for the first time in Turkey, the total 230 samples were collected in the average amount of $100 \mathrm{~g}$ from commercial and domestic alfalfa seeds for each location. These seeds were cultivated at $25 \pm 1{ }^{\circ} \mathrm{C}$ and $65 \pm 5 \% \mathrm{RH}$ in the laboratory. With the aim of determining the infection and damage rates, the adult insects emerging, the damaged and non-damaged seeds were counted and weighed for each sample. Consequently, it was determined that $94.8 \%$ of those samples collected for the study were infected with $B$. roddi and average 17060.54 seeds in those samples were damaged at the rate of $0.25 \%$ and the infection caused the weight loss of $0.09 \%$.
\end{abstract}

Keywords: Stored of alfalfa seeds, Bruchophagus roddi, infection and damage rates, Eastern Region, Turkey

\section{Doğu Anadolu Bölgesinde Depolanmış Yonca Tohumlarında Yonca Tohum Kalsidi Bruchophagus roddi Gussakovskiy, 1933 (Hymenoptera, Eurytomidae)'in Zararı ve Bulaşma Oranlarının Belirlenmesi}

ÖZET: Bu çalışma Yonca tohum kalsiti Bruchophagus roddi Gussakovskiy, 1933 (Hymenoptera, Eurytomidae)'nin bulaşma oranları ve zararını belirlemek amacıyla, 2013 ve 2014 yıllarında Iğdır, Kars ve Van illerinde 22 farklı yerde yerde yürütülmüştür. Çalışmalarda ortalama $100 \mathrm{~g}$ ağırlığında ticari ve çiftçilerden 230 tohumluk yonca toplanmıştır. Toplanan tohumlar $25 \pm 1{ }^{\circ} \mathrm{C}$ sıcaklıkta ve $65 \pm 5 \%$ nem ortamında laboratuvarda kültüre alınmıştır. Her bir örnekte ergin çıkışları gözlemlenmiş, bulaşma ve zarar oranlarını belirlemek amacıyla tohumlar tartılarak sayılmıştır. Sonuç olarak, toplanan örneklerin \% 94.8'nin bulaşık olduğu belirlenmiş ve ortalama 17060.54 tohum örneğininin $\% 0.25$ oranında zarar gördüğü ve $\% 0.09$ ağırlık kaybına uğradığı bulunmuştur.

Anahtar kelimeler: Depolanmış yonca tohumu, Bruchophagus roddi, bulaşma ve zarar oranları Doğu Anadolu Bölgesi, Türkiye

\footnotetext{
Presented at, Challenges in Modern Agricultural Production, Skopje, 7-9 October 2014

Makedonia, as a poster presentation.

Iğdır Üniversitesi, Ziraat Fakültesi, Bitki Koruma, Iğdır, Türkiye

2 Gıda Tarım ve Hayvancılık Bakanlığı, İlçe Tarım Müdürlüğü, Aralık, Iğdır, Türkiye

Sorumlu yazar/Corresponding Author: Celalettin GÖZÜAÇIK, cgozuacik46@gmail.com
} 


\section{INTRODUCTION}

Alfalfa, Medicago sativa $\mathrm{L}$. is a very significant forage crop throughout the world. It is rich in nutrition value and can be easily consumed by livestock (Elçi et al., 1994). Alfalfa production increased in all areas from the Aegean, Mediterranean and Black Sea coasts to the high plateaus of eastern Turkey (Manga et al., 1995). In Turkey, alfalfa is cultivated over 628642 ha and the amount of production from these areas was estimated to be 112616178 tonnes, in addition, 1154 tonnes alfalfa seed is produced (TUIK, 2013).

There are many insects that damage alfalfa growing areas. The alfalfa seed chalcid, B. roddi, is a key insect pest of alfalfa seed production of the worldwide (Nielson and Lehman, 1980). It is a member of the family Eurytomidae, order Hymenoptera. A phytophagous pest is the insect that feeds within seeds of alfalfa plant at all the larval stages, and plays a significant role in the seed production of alfalfa, economically. The adult chalcid is a small jet-black insect about $2.0 \mathrm{~mm}$ long together with a wing expanse of approximately 2.5 $\mathrm{mm}$. Males are smaller in body size than females and have 11-segmented antennae with whorls of long setae on the 8 proximal segments (Sorenson, 1930). They lay eggs in growing seed of alfalfa, one egg per seed. Each larvae consumes absolutely the interior of the seed and the adult wasp emerges by hollowing out coat of the seed in the form of a small round hole (Figure 2). In the harvest time, seeds containing immature chalcids are generally transferred to the store. Empty seed coats are thrown out with the chaff during harvest period.

There are two or more generations of alfalfa seed chalcid per growing season. The alfalfa seed chalcid overwinters at diapausing period of larva within the seed. In the final fall generation, it overwinters in the interior of seed and adults emerge in the spring (Nielson, 1976). In literature, alfalfa seed chalcid was first reported in 1972 by Tuatay et al (1972) in Turkey. Also, Tamer et al. (1997) addressed to be the harmful effects of Bruchophagus roddi Guss. in alfaalfa fields of Turkey (Tamer et al., 1997). However, published reports on the harmful effect of the insect pest on the alfaalfa seeds are still scarce. Hence, the present work was conducted to determine the infection and damage rates of the alfalfa seed chalcid, B. roddi on the stored alfalfa seeds in Iğdır, Kars and Van provinces of the Eastern Anatolia Region in the years 2013-2014.

\section{MATERIAL AND METHOD}

The study was conducted at 22 locations of Iğdır, Kars, and Van provinces of the Eastern Anatolia Region between October and December in 2013 with the aim of determining the infection and damage rates of the alfalfa seed chalcid, B.roddi for the stored alfalfa seeds between January and February months of the year 2014. In the study, the total $(n=230)$ samples seed were collected from $(n=196)$ commercial and $(n=34)$ domestic alfalfa seeds for each location between 8 october 2013 and 13 February 2014 (Table 1). These seeds were cultivated separately at the laboratory. After sieving seeds were cultivated as each $50 \mathrm{ml}$, except a tube $(2 \times 8 \mathrm{~cm})$ wrapped with aluminum foil in 230 cardboard cups at $25 \pm 1{ }^{\circ} \mathrm{C}$ and $65 \pm 5 \%$ $\mathrm{RH}$ at the laboratory. It was waited until adult emergence ceased in tubes. The adult chalcids within the tubes were counted and recorded. The presence of the chalcids in each cardboard cup was also examined, and then infected and noninfected seeds were counted again and weighed. Bruchophagus roddi was identified by Prof. Dr. Halit Çam (Gaziosmanpasa University, Faculty of Agriculture, Department of Plant Protection, Tokat / Turkey).

\section{RESULTS AND DISCUSSION}

In the study conducted to determine the infection and damage rates of the alfalfa seed chalcid, $B$. roddi on alfalfa seeds stored in the Eastern part of Turkey during 2013-2014, a total of 230 seed samples with 196 domestic and 34 commercial samples were collected from three provinces and the obtained results are presented in Table 2 . 
Table 1. The number of samples from the locations in the years 2013-2014.

\begin{tabular}{|c|c|c|c|c|c|}
\hline Provinces & District & Locations & $\begin{array}{c}\text { Number of } \\
\text { domestic seed } \\
\text { samples (n) }\end{array}$ & $\begin{array}{c}\text { Number of } \\
\text { commercial seed } \\
\text { samples (n) }\end{array}$ & $\begin{array}{l}\text { Number of } \\
\text { sample (n) }\end{array}$ \\
\hline \multirow{18}{*}{ Iğdır } & Center & Center & 13 & 6 & 19 \\
\hline & \multirow{11}{*}{ Aralık } & Karasu mahallesi & 6 & - & 6 \\
\hline & & Aşağı Çiftlik & 42 & - & 42 \\
\hline & & Yukarı Çiftlik & 7 & - & 7 \\
\hline & & Ortaköy & 18 & - & 18 \\
\hline & & Yukarı Aratan & 22 & - & 22 \\
\hline & & Aşağı Aratan & 2 & - & 2 \\
\hline & & Hacıağa & 7 & - & 7 \\
\hline & & Tazeköy & 12 & - & 12 \\
\hline & & Aşağı Topraklı & 2 & - & 2 \\
\hline & & Yukarı Topraklı & 1 & - & 1 \\
\hline & & Aşağı Çamurlu & - & 3 & 3 \\
\hline & \multirow{2}{*}{ Karakoyun } & Göl mahallesi & 4 & - & 4 \\
\hline & & Merkez & 4 & - & 4 \\
\hline & \multirow{4}{*}{ Tuzluca } & Karanlıkköy & 4 & - & 4 \\
\hline & & Bahçeli Meydan köyü & 2 & - & 2 \\
\hline & & Gaziler & 18 & - & 18 \\
\hline & & Ağabey & 4 & - & 4 \\
\hline Kars & Digor & Merkez & 4 & 25 & 29 \\
\hline \multirow{3}{*}{ Van } & \multirow{2}{*}{ Erciş } & Merkez & 7 & - & 7 \\
\hline & & Ağaçören & 10 & - & 10 \\
\hline & Muradiye & Merkez & 7 & - & 7 \\
\hline \multicolumn{2}{|c|}{ Total } & 22 & 196 & 34 & 230 \\
\hline
\end{tabular}


Table 2. Collected samples ( for $50 \mathrm{ml}$ ) in the Igdir, Kars and Van provinces in the years 2013-2014

\begin{tabular}{|c|c|c|c|c|c|c|c|c|c|}
\hline : & Townships & Locations & $\begin{array}{c}\text { Average } \\
\text { number of } \\
\text { seed }\end{array}$ & $\begin{array}{c}\text { Average } \\
\text { number of } \\
\text { ASC* }\end{array}$ & $\begin{array}{c}\text { Average } \\
\text { number of } \\
\text { damaged } \\
\text { seed }\end{array}$ & $\begin{array}{c}\text { Average } \\
\text { rates of } \\
\text { infected } \\
(\%)\end{array}$ & $\begin{array}{l}\text { Average } \\
\text { weight of } \\
\text { seed } \\
\text { (g) }\end{array}$ & $\begin{array}{l}\text { Average } \\
\text { weight of } \\
\text { damaged } \\
\text { seed } \\
\text { (g) }\end{array}$ & $\begin{array}{c}\text { Average } \\
\text { rate of } \\
\text { damage }(\%)\end{array}$ \\
\hline \multirow{18}{*}{ 寻 } & Merkez & Merkez & 14640.1 & 0.8 & 13.1 & $0.10 \pm 0.11$ & $38.77 \pm 9.56$ & $0.02 \pm 0.01$ & $0.10 \pm 0.04$ \\
\hline & \multirow{11}{*}{ Aralık } & Karasu, & 14863.2 & 0 & 31.8 & $0.42 \pm 0.40$ & $30.36 \pm 6.71$ & $0.03 \pm 0.01$ & $0.11 \pm 0.07$ \\
\hline & & Aşağı Çiftlik & 20407.2 & 7.2 & 36.1 & $0.18 \pm 0.14$ & $43.61 \pm 5.71$ & $0.03 \pm 0.02$ & $0.10 \pm 0.05$ \\
\hline & & Y. Çiftlik & 18666.6 & 5.3 & 41.4 & $0.23 \pm 0.13$ & $42.41 \pm 7.04$ & $0.04 \pm 0.02$ & $0.01 \pm 0.05$ \\
\hline & & Ortaköy & 17074.7 & 11.2 & 64.6 & $0.42 \pm 0.44$ & $37.36 \pm 8.33$ & $0.06 \pm 0.06$ & $0.11 \pm 0.06$ \\
\hline & & Y. Aratan & 15180.1 & 6.1 & 47.3 & $0.32 \pm 0.31$ & $36.00 \pm 8.33$ & $0.04 \pm 0.04$ & $0.13 \pm 0.11$ \\
\hline & & Aşağ Aratan & 15085.0 & 6.5 & 25.0 & $0.17 \pm 0.02$ & $37.39 \pm 6.70$ & $0.02 \pm 0.01$ & $0.05 \pm 0.03$ \\
\hline & & Hacıağa & 21724.1 & 15.7 & 57.9 & $0.28 \pm 0.10$ & $45.97 \pm 4.95$ & $0.04 \pm 0.02$ & $0.10 \pm 0.05$ \\
\hline & & Tazeköy, & 20860.8 & 0.8 & 8.6 & $0.04 \pm 0.03$ & $41.99 \pm 2.81$ & $0.01 \pm 0.01$ & $0.03 \pm 0.02$ \\
\hline & & $\begin{array}{l}\text { Aşağ1 } \\
\text { Toprakl1 }\end{array}$ & 21699.5 & 35.0 & 120.5 & $0.56 \pm 0.01$ & $44.69 \pm 0.21$ & $0.07 \pm 0.02$ & $0.15 \pm 0.05$ \\
\hline & & Y.Topraklı & 7132.0 & 0 & 00.0 & $0.00 \pm 0.00$ & $36,94 \pm 0.00$ & $0.00 \pm 0.00$ & $0.00 \pm 0.00$ \\
\hline & & $\begin{array}{l}\text { Aşağı } 1 \\
\text { Çamurlu }\end{array}$ & 10057.0 & 0 & 4.3 & $0.04 \pm 0.02$ & $39.84 \pm 4.43$ & $0.01 \pm 0.01$ & $0.02 \pm 0.02$ \\
\hline & \multirow{2}{*}{$\begin{array}{l}\text { Kara- } \\
\text { koyun }\end{array}$} & Göl mah. & 18727.8 & 1.0 & 18.8 & $0.08 \pm 0.06$ & $41.98 \pm 2.64$ & $0.07 \pm 0.09$ & $0.01 \pm 0.02$ \\
\hline & & Merkez & 19985.0 & 19.5 & 93.0 & $0.47 \pm 0.36$ & $42.03 \pm 7.93$ & $0.07 \pm 0.05$ & $0.20 \pm 0.12$ \\
\hline & \multirow{4}{*}{ Tuzluca } & Karanlıkköy & 10810.0 & 0.5 & 18.8 & $0.18 \pm 0.05$ & $26.59 \pm 2.23$ & $0.03 \pm 0.01$ & $0.10 \pm 0.03$ \\
\hline & & B. Meydan & 16058.0 & 102.5 & 203.0 & $1.29 \pm 0.12$ & $40.34 \pm 1.32$ & $0.09 \pm 0.04$ & $0.21 \pm 0.08$ \\
\hline & & Gaziler & 16688.1 & 5,4 & 24,6 & $0.15 \pm 0.20$ & $37.57 \pm 6.33$ & $0.03 \pm 0.02$ & $0.10 \pm 0.06$ \\
\hline & & Ağabey & 20091.3 & 0 & 3,0 & $0.02 \pm 0.02$ & $52.86 \pm 11.3$ & $0.01 \pm 0.01$ & $0.01 \pm 0.02$ \\
\hline$\stackrel{\mathscr{z}}{\underline{\Xi}}$ & Digor & Merkez & 14143.9 & 6.0 & 19.8 & $0.15 \pm 0.08$ & $38.03 \pm 5.64$ & $0.02 \pm 0.02$ & $0.10 \pm 0.05$ \\
\hline \multirow{3}{*}{$\stackrel{\approx}{>}$} & \multirow{2}{*}{ Erciş } & Center & 22158.7 & 19.9 & 69.1 & $0.32 \pm 0.20$ & $44.80 \pm 3.04$ & $0.04 \pm 0.02$ & $0.01 \pm 0.04$ \\
\hline & & Ağaçören & 20948.9 & 2.9 & 15.5 & $0.07 \pm 0.03$ & $43.44 \pm 4.43$ & $0.01 \pm 0.02$ & $0.04 \pm 0.03$ \\
\hline & Muradiye & Merkez & 18329.9 & 2.3 & 20.6 & $0.11 \pm 0.07$ & $39.87 \pm 3.53$ & $0.03 \pm 0.02$ & $0.10 \pm 0.03$ \\
\hline & & Average & 17060.54 & 11.3 & 42.6 & $0.25 \pm 0.28$ & $40.13 \pm 5.39$ & $0.035 \pm 0.02$ & $0.088 \pm 0.06$ \\
\hline
\end{tabular}

* ASC: Alfalfa Seed Chalcid 
As also understood from Table 2, the adult alfalfa seed chalcids emerged with an average of 11.3 number (min.0, max.102.5) in laboratory during Mart and April months of the year 2014. No adult chalcids were obtained for 12 samples of native seeds. Of all the evaluated seed samples, 218 emerged as the adult insects (Figure 1). Under the investigation, alfalfa seed chalcids could not be found in Karasu (n=6), Așağ 1 Çamurlu $(n=3)$ and Ağabey $(n=4)$ locations, whereas the chalcids were available in all other locations. No alfalfa seed chalcid and damaged seed were determined in Yukarı Toprakl1 $(n=1)$ among the examined locations. In the study, the infection rate of samples from only Igdir province was 93.2 (\%), but all the samples of Kars and Van provinces were found to be infected. Eventually, It was concluded that $B$. roddi was common in all three provinces with overall infection rate of $94.8 \%$.

In the western USA, seed growers obtained the infection rate with the wide range of $5 \%$ to $83 \%$ (Urbahns, 1920; Sorenson, 1934; Bacon, et al., 1959). Similar rates have also been reported from Russia (Kolobova, 1950). Of 17103.14 seeds evaluated in the study, 17060.54 were non-infected, and only 42.6 seeds were determined to be infected. The rate of the infected seeds was 0.25 . With Table 2 , it was suggested to be $40.13 \mathrm{~g}$ non-infected, $0.035 \mathrm{~g}$ damaged, and
0.09 damaged rate of $40.165 \mathrm{~g}$ seeds. Therein, these low results may be ascribed to various operations like blowing and sieving made by farmers before the store.

Hanson (1962) referring to McAllister (1958) reported that the chalcids at larval and pupal stages of the fall generation overwinter within seeds, and emerged as adults in the following spring, as well as proved that loss rate due to the seed chalcids was roughly $80 \%$ for the alfaalfa seeds produced in Oklahoma. In fact, the loss was mostly indiscernible due to the fact that the seeds were very small (Soroka and Otani, 2011).

The present results supported those obtained by Soroka and Spurr (1998), who referred that winter hardy cultivars becoming dormant early in the Autumn season had lower levels of the chalcid-damaged seeds (Figure 3) compared with less hardy cultivars maintaining growth later in the season. In the earlier study, it was reported by Peterson et al. (1991) that high variability was observed in the damage owing to trefoil seed chalcids between years. Previously, De Barro (2001) has mentioned that alfaalfa seed chalcids led to the economically significant losses. Further studies on the loss of the chalcids and the effective factors on the loss should be conducted under various conditions due to economic causes.

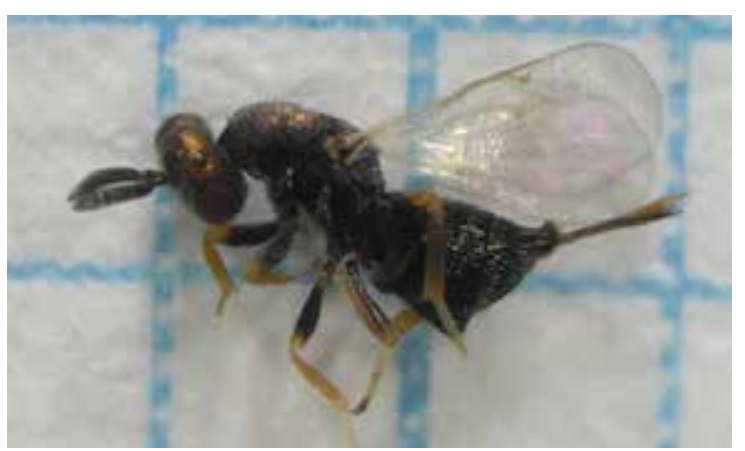

Figure 1. Adult of Bruchophagus roddi

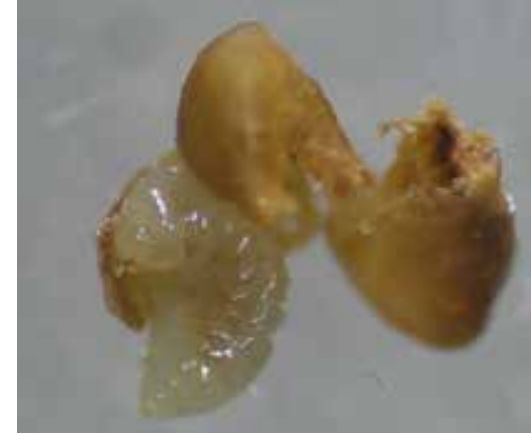

Figure 2. Larvae

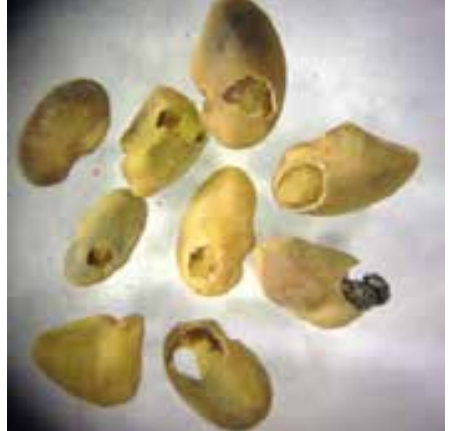

Figure 3. Damage

\section{CONCLUSION}

This study was the first report on determining the infection and damage rates of the alfalfa seed chalcid, B. roddi on alfalfa seeds provided from the stores of 22 locations in Iğdır, Kars and Van provinces of the Eastern Anatolia region during 2013-2014 years. It was determined that $94.8 \%$ of the studied samples were infected with $B$. roddi and average 17060.54 seeds in all the samples were damaged with the very low rate of $0.25 \%$ and the infection caused the weight loss of $0.09 \%$. The rates of infected and damaged seeds were found very low as a result of sieving and seed cleaning. Thus, the damaged seeds were lighter in weight. More detailed studies should be conducted about distribution, biology, damage and control methods of the insect which can cause economic losses at big rates. In conclusion, we recommend that alfalfa producers sowing with infected seeds should be avoided. 


\section{ACKNOWLEDGMENT}

Weare gratefultoProf.Dr.HalitÇam(Gaziosmanpaşa University. Faculty of Agriculture. Department of Plant Protection. Tokat/Turkey) for identifying the specimen.

\section{REFERENCES}

Carrillo SJL, Dickason EA, 1963. Biology and economic importance of seed chalcids infesting red clover and alfalfa in Oregon. Technical Bulletin. Oregon Agricultural Experiment Station. No 68:1-35.

De Barro J, 2001. Evaluating and managing lucerne seed wasp in lucerne seed crops. RIRDC Publication, no.1/136.

Elçi Ş, Kolsarıcı Ö and Geçit HH, 1994. Tarla Bitkileri, 2. Baskı, Ankara Üniversitesi Ziraat Fakültesi Yayınları: 1385, Ders Kitab1: 399, Ankara

Hanson CH, 1962. Report of the eighteenth alfalfa improvement conference, United States Department of Agriculture, Agricultural Research Service Crops Research DivisionJune 25-28, Davis, California, p 103.

Manga Ü, Acar Z, Ayan Ü, 1995. Baklagil Yem Bitkileri. OndokuZ Mayıs Üniversitesi Ziraat Fak. Ders Notu No: 7.

Nielson MW, 1976. Diapause in the alfalfa seed chalcid, Bruchophagus roddi (Gussakovsky), in relation to natural photoperiod. Environmental Entomology, 5: 123-127.

Nielson MW and Lehman WF, 1980. Breeding approaches in alfalfa. In: Breeding Plants Resistant to Insects, F.G. Maxwell and P.R. Jennings, eds. 683 pp.

Peterson SS, Wedberg JL and Hogg DB, 1991. Postdiapause development and phenology of the trefoil seed chalcid (Hymenoptera: Eurytomidae) and its parasitoids. Environmental Entomology, 20: 1606-1611.

Soroka JJ, and Spurr DT, 1998. Geographic incidence and damage levels of alfalfa seed chalcid, Bruchophagus roddi (Hymenoptera: Eurytomidae), in Saskatchewan, and its relationship to weather and agronomic variables and production practices. The Canadian Entomologist, 130: $1-11$.

Soroka,JJ and Otani JK, (2011). "Arthropods of Legume Forage Crops.”, in Floate, K.D. (ed.) - Arthropods of Canadian Grasslands. Vol. 2: Inhabitants of a Changing Landscape, Biological Survey of Canada (BSC), Chapter 10, pp. 239264.

Sorenson CJ, 1930. The alfalfa seed chalcis-fly in Utah 1926-29, inclusive. Utah Agr. Exp. Sta. Bull. 218: 33 pp.

Tamer A, Aydemir M, Has A, 1997. Ankara ve Konya illerinde korunga ve yonca da görülen zararlı ve faydalı böcekler üzerinde faunistik çalışmalar .Bitki Koruma Bülteni ,37(34) : 125-161.

Tuatay N, Kalkandelen A and Aysev N, 1972. Nebat Koruma Müzesi Böcek Kataloğu (1961 - 1971). Yenigün Matbaası, Ankara, 119 pp. (In Turkish).

TUIK, 2014. Bitkisel Üretim İstatistikleri. www.tuik.gov.tr. Access to:24.09.2014 